\title{
When is it Safe for Patients to Drive after Right Total Hip Arthroplasty?
}

\author{
Victor H. Hernandez, MD \\ Rothman Institute at Thomas Jefferson University \\ Alvin C. Ong, MD \\ Rothman Institute at Thomas Jefferson University \\ Fabio Orozco, MD \\ Rothman Institute at Thomas Jefferson University \\ Anne Marie Madden \\ Rothman Institute at Thomas Jefferson University
}

Zachary D. Post, MD

The Rothman Institute of Orthopedics at Thomas Jefferson University Hospital Follow this and additional works at: https://jdc.jefferson.edu/rothinsposters

Part of the Orthopedics Commons

Let us know how access to this document benefits you

\section{Recommended Citation}

Hernandez, MD, Victor H.; Ong, MD, Alvin C.; Orozco, MD, Fabio; Madden, Anne Marie; and Post, MD, Zachary D., "When is it Safe for Patients to Drive after Right Total Hip Arthroplasty?" (2015). Rothman Institute Conference Posters. Paper 11.

https://jdc.jefferson.edu/rothinsposters/11

This Article is brought to you for free and open access by the Jefferson Digital Commons. The Jefferson Digital Commons is a service of Thomas Jefferson University's Center for Teaching and Learning (CTL). The Commons is a showcase for Jefferson books and journals, peer-reviewed scholarly publications, unique historical collections from the University archives, and teaching tools. The Jefferson Digital Commons allows researchers and interested readers anywhere in the world to learn about and keep up to date with Jefferson scholarship. This article has been accepted for inclusion in Rothman Institute Conference Posters by an authorized administrator of the Jefferson Digital Commons. For more information, please contact: JeffersonDigitalCommons@jefferson.edu. 


\section{When is it Safe for Patients to Drive after} Right Total Hip Arthroplasty?

\section{INTRODUCTION}

Driving restrictions after total hip arthroplasty (THA) can be inconvenient and burdensome for patients.

When patients may safely be allowed to drive remains controversial.

Most studies recommend 6 weeks but recent advances in surgical approach, pain management and rapid recovery may have changed this time frame.

The purpose of this study was to prospectively evaluate driving safety after THA through brake reaction time.

\section{MATERIALS AND METHODS}

Twenty nine patients who underwent right THA were prospectively evaluated between October 2013 and June 2014.

Driving performance was evaluated using the Brake Reaction Test (BRT) measuring brake time after a stimulus (Figure 1). All patients underwent preoperative assessment to establish a baseline. Patients were then re-tested at 2, 4 and 6 weeks post operatively. Patients were allowed to drive when the post-operative reaction time was equal to or less than the pre-operative baseline. In addition at each testing patients were asked if they felt ready to drive.

General linear repeated measurement was used for analysis.

\section{RESULTS}

Of the 38 study patients, 33 (87 \%) reached their baseline time by 2 weeks. Five patients (13\%) reached their baseline at 4 weeks. There were no differences with respect to age, gender, or the use of assistance devices. Of the 33 patients, 24 (73\%) stated that they felt ready to drive while $5(15 \%)$ were not sure and $4(12 \%)$ felt they were not ready. Of the 5 patients who returned to baseline at 4 weeks, 2 patients said they thought they were ready while 3 patients did not.

However, even the five patients that did not return to their baseline by two weeks were still under the nationally recommended safe brake time standard of 1.25 seconds which is based upon several scientific studies looking at BRT in all types of patients, surgical and non-surgical alike

\section{TABLE 1}

\begin{tabular}{|l|c|c|c|c|c|}
\hline Patient & Age (years) & Gender & T - Pre & T 2-W & T 4-W \\
\hline 1 & 75 & Female & 0.703 & 1.03 & 0.566 \\
\hline $\mathbf{2}$ & 52 & Male & 0.593 & 0.638 & 0.567 \\
\hline 3 & 51 & Male & 0.454 & 0.478 & 0.449 \\
\hline 4 & 54 & Female & 0.598 & 0.640 & 0.472 \\
\hline 5 & 64 & Female & 0.515 & 0.674 & 0.455 \\
\hline
\end{tabular}

Table 1: Characteristic of the 5 patients that did not reached their baselines at the 2-weeks.
T=time: Pre= Pre-operative: W=-Week

\section{FIGURE 1}

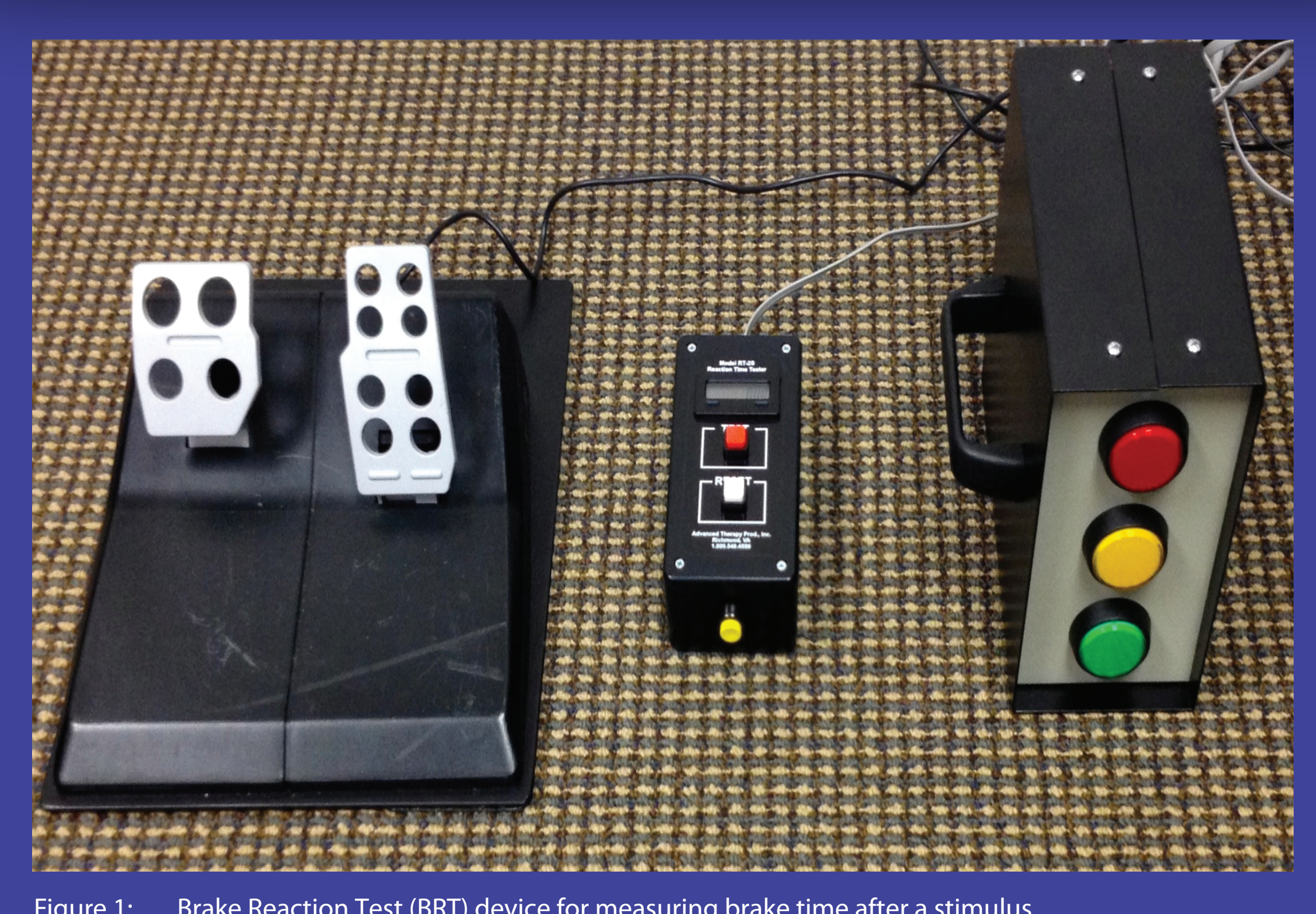

gure 1: Brake Reaction Test (BRT) device for measuring breke time after a stimulus

\section{DISCUSSION}

Nearly all patients were able to return to normal BRT by 2 weeks after THA. In addition, patient perception of driving ability accurately predicted return of BRT. This represents a substantial improvement from current recommendations.

These findings have allowed us to encourage patients to reevaluate their driving ability as soon as 2 weeks after THA. 